Saudi Journal of Economics and Finance

Abbreviated Key Title: Saudi J Econ Fin

ISSN 2523-9414 (Print) |ISSN 2523-6563 (Online)

Scholars Middle East Publishers, Dubai, United ArabEmirates Journal homepage: http://saudijournals.com/sjef/

Original Research Article

\title{
Determinant Factors of the Tax Compliance in SMEs: Indonesia Cases
}

Hersen Stefanus*, Wiwik Utami

Universitas Mercu Buana, Jl. Meruya Selatan No.1, RW.1, Meruya Sel., Kec. Kembangan, Kota Jakarta Barat, Daerah Khusus Ibukota Jakarta 11650, Indonesia

\begin{tabular}{l|l|l|l|}
\hline DOI: $10.36348 /$ SJEF.2019.v03i09.005 & Received: 27.08.2019| Accepted: 05.09.2019| Published: 29.09 .2019
\end{tabular}

*Corresponding author: Hersen Stefanus

\section{Abstract}

This study aims to obtain an empirical evidence related to the inflluence of tax officers service quality, tax understanding, tax sanction, and public trust to the taxpayers compliance. The population of this study is SMEs located in Tanah Abang Market, Central Jakarta. The number of samples is determined using the slovin formula which found samples 100 SMEs who located in Block a Tanah Abang Market. The data were collected using a questionnaire which used likert scale. The data analysis method used is Partial Least Square (PLS). The result showed that tax officers service quality, tax understanding, tax sanction, and public trust have positive significance effect on the taxpayers compliance.

Keywords: service quality, tax understanding, tax sanction, taxpayer compliance.

Copyright @ 2019: This is an open-access article distributed under the terms of the Creative Commons Attribution license which permits unrestricted use, distribution, and reproduction in any medium for non-commercial use (NonCommercial, or CC-BY-NC) provided the original author and source are credited.

\section{INTRODUCTION}

The development is important carried out by a country. The development aims to achieve prosperity and welfare of the people. The development requires a huge funds. So the government really needs the taxes as a source of funding for the development.
Taxes always make a record as the largest and the most dominant portion if compared to other state revenues. In 2017 State Budget (APBN) recorded that the revenues from tax sector accounted for $85.6 \%$ of the total domestic revenue sources. This proves that the tax revenue is very important to the country.

Table-1: Target-Realization of Tax Income Revenue (Trillion Rupiah)

\begin{tabular}{|c|c|c|c|c|}
\hline \multirow{2}{*}{ Year- } & Tax Revenue Target & Tax Revenue Realization & Ratio & Compliance Ratio \\
\hline & Trillion Rupiah & Trillion Rupiah & Target-Realization (\%) & $\%$ \\
\hline 2012 & 520,00 & 465,10 & 89,00 & 52,31 \\
\hline 2013 & 548,90 & 506,40 & 87,00 & 56,21 \\
\hline 2014 & 586,30 & 546,20 & 93,00 & 59,12 \\
\hline 2015 & 644,40 & 602,30 & 93,00 & 60,42 \\
\hline 2016 & 757,20 & 855,80 & 113,00 & 63,15 \\
\hline
\end{tabular}

In Table-1, it can be seen that although the realization of tax revenue has almost never reached the target, but there was always an increase in the target achievement ratio every year when in 2016 the realization has exceeded the target set with a ratio of $113 \%$. But actually the realization of the tax revenue can be achieved far more than that if the taxpayer compliance can be increased, seeing the low ratio of taxpayers compliance in 2016 only $63 \%$ of the total registered taxpayers who obediently carry out their tax obligations.

Seeing this fact, Minister of Finance Sri Mulyani said that the government would improve the tax administration. The government will encourage improvement in Director General of Tax (DGT) by developing and strengthening the professionalism and integrity of the human resources in taxation services. In addition, Sri Mulyani also acknowledged that the complexity of the taxation regulations is one of the causes of low tax compliance. This has an impact on the difficulty of taxpayers to understand these regulations so that the tax understanding also became low. Then, Sri Mulyani explained that she would amend the General Provisions and Tax Procedures Law (UU KUP) and the Income Tax Law (UU PPh). Tax regulations will be improved then will not create complexity 
anymore and can increase taxpayers compliance.

(www.detik.com, 10/20/16). [1]

President of the Southern Economic Association James said that tax compliance is highly dependent on the understanding and motivation of individuals and companies to pay or not pay the taxes. The motivation of taxpayers can be increased through the sanction application. James also agreed with Sri Mulyani that another way to increase the taxpayers compliance could be pursued by improvements in tax administration, namely providing simpler and easier services for taxpayers in paying taxes. However, the government must be able to build trust and convince the public that the taxes paid can be managed properly (www.koransulindo.com, 10/21/16). [2]

In line with James's statement regarding the importance of the public trust in the tax management, Hestu stated that the low tax compliance indeed due to the negative perceptions in the eyes of the public, such as the corruption mindset or the perception of corruption behavior related to tax implementation in Indonesia (www.viva.co.id , 11/15/16). [3]

Based on the statement of some experts above, it can be said that the low taxpayers compliance is influenced by four factors, namely the poor quality of services, the complexity of tax laws, the lack of taxpayers motivation to pay taxes, and the low public trust.

The service quality can influence the taxpayers compliance. Poor service can cause taxpayers to be reluctant to pay taxes.

Alabede, Ariffin, and Idris (2010) conducted a study in Nigeria regarding the service quality and concluded that the public perception about the quality of tax services had a positive and significant effect on taxpayers compliance behavior .[4] Meanwhile, the research was done by Madjid (2015) concluded that the quality of taxation services does not have an effect on the tax compliance. [5]

The tax understanding can influence the taxpayers to comply with. The taxpayers may not be able to obey if they do not understand what they have to do related to the their tax obligation.

The research that examined the effect of tax understanding on tax compliance has been conducted by Xin, Khai, Fong and Chen (2015) which stated that the biggest obstacle for the malaysian individual taxpayers to carry out their tax obligations is their low tax understanding. [6] Meanwhile, the results of Engida and Baisa's (2014) research in Ethiopia concluded that understanding the tax does not significantly influence the tax compliance.[7]
The motivation of taxpayers can encourage taxpayers compliance. The application of tax sanction can cause that taxpayers motivation to comply with. Tax sanction is a deterrent for the taxpayers not to violate the law of taxation.

Lesnik, Tomaz, Kracun, Davorin, Jagric, and Timotej (2014) conducted a study in Slovenia regarding tax sanction which concluded that the tax sanction has a positive effect on the compliance.[8] Meanwhile, Engida and Baisa (2014) conducted a study in Ethiopia, concluded that the tax sanction does not significantly influence the tax compliance.

The public trust can influence the taxpayers compliance. Taxpayers who do not trust in government are definitely reluctant to pay the taxes.

Birskyte (2014) conducted a study in Romania about the public trust which concluded that there is a positive influence between the public trust and the taxpayers compliance, where the taxpayers will be motivated to comply with if the taxpayers believe in their government. [9] Meanwhile, Dharma and Ariyanto (2014) concluded that public trust does not affect taxpayers compliance.[10]

The allegation of the influence of those aspects to tax compliance and the inconsistency of the results of previous studies, encouraged authors to re-examine those aspects with the different conditions, times, and research objects. Based on this background, the author will examine the influence of perceptions of tax officers service quality, tax understanding, perception of tax sanction, and public trust to the taxpayers compliance.

\section{LITERATURE REVIEW Attribution Theory}

According to Heider (Suartana; 2010), attribution can be divided into internal attributions, which is a person's behavior arises caused by internal factors such as attitudes, certain traits, or other internal aspects and external attributions, which is, someone's behavior arises caused by a situation or environment outside of the person.[11] Related to the taxpayers compliance, the behavior of taxpayers to comply with is also caused by the internal factors such as tax understanding and public trust as well as external factors of taxpayers such as tax officers service quality and tax sanction.

\section{Perception of Tax Officers Service Quality}

Lewis and Blooms quoted by Tjiptono (2012) stated that the service quality is simply interpreted as a measure of how is the services provided is able to meet the customer expectations.[12] Then the perception of the tax officers service quality is the perception of taxpayers towards the services provided by tax officers 
related to how are the services can meet the needs of taxpayers.

\section{Tax Understanding}

The tax system enacted in Indonesia is self assessment system. Self assessment system is the tax system that give the authority to taxpayers to calculate, pay, and report their own tax obligation (Waluyo and Ilyas, 2015) [13] In order to taxpayers can do their tax obligation by themselves, taxpayers need to have a good tax understanding. According to Big Dictionary of Indonesian Language (KBBI), understand is interpreted as really understand or really know, while understanding is interpreted as an effort to understand.[14] In the other hand, understanding is knowing about something and being able to see in various aspects. Then tax understanding is the ability of taxpayers to understand the whole tax laws and regulations.

\section{Perception of Tax Sanction}

Mardiasmo (2018) stated that the tax sanction are the guarantee for the provisions of tax laws will be obeyed.[15] Tax sanction are a deterrent for the taxpayers not to violate taxation laws. Devano and Rahayu (2006) argue that the taxpayers will comply with because they think there are severe sanction due to illegal actions in their efforts to smuggle taxes, so that the the tax sanction can increase taxpayers compliance.[16]

\section{Public Trust}

Zain (2008) stated that the trust is giving the trust to someone to maintain, preserve, save, keep secret, and so on. [17] The public trust is the trust of the people to their government to always provide the best for them. Turnipseed (2009) stated that "public trust doctrine is simple, but a powerful legal concept that obliges governmental institutions to manage public resources to the best interest of its citizens and by not compromising with the benefits of future generations ". [18] Frederickson and Ghere (2015) also stated that " our collective trust in government relies on a robust perception that government employees are acting in the public interest ". [19]

\section{Tax Compliance}

According to KBBI, compliance means comply with the regulation. Siat and Toly (2013) stated that the compliance is the motivation of a person, group, or organization that does or does not comply with the established rules. [20] As the above theory, it can be concluded that the tax compliance is a taxpayer's motivation to comply with the applicable taxation provisions or rules. The same thing is also stated by James and Alley (2010) that "the tax compliance refers to the willingness of individuals to act in accordance with both the 'spirit' and the 'letter' of the tax law and administration without the application of enforcement activity". [21]

\section{Hypothesis}

The Influence of Perception of Tax Officers Service Quality on the Taxpayers Compliance

The one factor that affect taxpayers compliance is the services to taxpayers (Rahayu, 2009).

[22] The good services can encourage taxpayers to comply with, otherwise the bad services can make taxpayers reluctant to comply with in carrying out their tax obligations.

H1: The perception of tax officers service quality has a positive effect on the taxpayers compliance.

\section{The Influence of Tax Understanding on the Taxpayers Compliance}

The taxation system adopted in Indonesia is a Self Assessment System, which the taxpayers have the obligation to calculate, pay, and report their own taxes by themselves. The taxpayers who do not understand what their tax obligations are and how to carry out their tax obligations, definitely cannot comply with the tax regulations. Therefore, the tax understanding is an important factor for the taxpayers to be compliant.

$\mathrm{H} 2$ : The tax understanding has a positive effect on the the taxpayers compliance.

\section{The Influence of Perception of Tax Sanction on the Taxpayers Compliance}

Tax sanction is the sanction imposed on the taxpayers who does not comply with in carrying out their tax obligations. The existence of the rules and law enforcement related to the tax sanction for noncompliant taxpayers can encourage taxpayers to carry out their tax obligations in accordance with the applicable regulations. So it can be said that the existence of tax sanction is very important to increase taxpayer compliance.

H3: The perception of tax sanction has a positive effect on the the taxpayers compliance.

\section{The Influence of Public Trust on the Taxpayers Compliance}

The public trust is the trust of the people to their government. If in the eyes of the taxpayers, the government can utilize the tax it received for the greatest prosperity of the people, then the taxpayers will trust in the government. With this trust, taxpayers will voluntarily do their tax obligations. It can be concluded that the public trust is an important factor in increasing taxpayers compliance.

H4: The public trust has a positive effect on the taxpayers compliance.

\section{RESEARCH METHODS}

The population in this study is located in Tanah Abang Market, Central Jakarta. The number of samples is determined using the slovin formula, which is 100 SMEs in Block A Pasar Tanah Abang, Central Jakarta. The sampling technique used was purposive sampling. The data were collected using a questionnaire method with a likert scale. The data analysis method 
used is Partial Least Square (PLS).

\section{RESULT AND DISCUSSION \\ The Description of Perceptions of Tax Officers Service Quality}

In table 2, it can be seen that the perception of tax officers service quality consists of 5 dimensions with the lowest average value is assurance at 3.90, which means that the competence and friendliness of tax officers are still not good enough. While the highest average value is responsiveness at 4.18 , which means that tax officers can provide the services immediately when it is needed. The average value of the perception of tax officers service quality in overall is 4.08 , which means that SMEs taxpayers in Tanah Abang Market perceive that the service quality of tax officers are quite good although in terms of competence and friendliness is considered to be still not good enough.

\section{The Description of Tax Understanding}

In table 3, it can be seen that the tax understanding consists of 3 dimensions with the lowest average value is the understanding of reporting, which is 4.12, which means SMEs taxpayers have a good understanding in reporting taxes. While the highest average value is the understanding of counting at 4.14, which means that SMEs taxpayers have a good understanding in calculating taxes also. In overall, the average value of tax understanding is 4.13, which means that The SMEs Taxpayers in Tanah Abang Market have a fairly good tax understanding in those three aspects which are calculating, paying, and reporting taxes.

\section{The Description of Perception of Tax Sanction}

In table 4, it can be seen that the perception of tax sanction consists of 3 dimensions with the lowest average value is the benefits of tax sanction at 3.91, which means that the tax sanction imposition is less effective because the sanction are not able to make the taxpayers deterrent, educated, and afraid not to violate taxes. While the highest average value is the severity of tax sanction is 4.06 , which means that the tax sanction imposed are already been heavy enough for SMEs taxpayers. In overall, the average value of perception of tax sanction is 3.95 , which means that the tax sanction are less effective applied, especially on the lack of benefits and the lack of firmness in applying the tax sanction.

\section{The Description of Public Trust}

In table 5, it can be seen that the public trust consists of 3 dimensions with the lowest average value is the spirit of transparency and culture of accountability which is 3.93 , which means that DGT institution is still not good enough in terms of transparency and accountability. While the highest average value is the people of integrity at 4.16 , which means that DGT employees have a good integrity which is shown in the form of high responsibility and honest and clean behavior in carrying out their work. In overall, the average value of public trust is 3.98 which means that the public trust in DGT is poor. That is because of the lack of transparency and accountability of DGT institution, although in terms of integrity, DGT employees are considered be quite good because they have good responsibilities and honest behavior.

\section{The Description of Taxpayers Compliance}

In table 6 , it can be seen that the taxpayers compliance consists of 2 dimensions, namely administrative compliance with an average value at 4.30 and material compliance with an average value at 4.29. In overall, the average value of tax compliance of taxpayers is at 4.29. This means that SMEs taxpayers compliance in Tanah Abang Market is good enough, both in terms of administrative and material.

\section{The Validity Test (Outer Model)}

Based on the output of SmartPLS, the loading factor value for all indicators meets convergent validity that is more than 0.7 and all loading factors between the indicators and it's dimensions are higher than the loading factors value between the indicator and other dimensions which means it also meets discriminant validity, so that all indicators in this study is declared valid

\section{The Reliability Test (Outer Model)}

Based on the output of SmartPLS, all the variables have the composite reliability more than 0.6 and Cronbach's alpha more than 0.7 then it can be concluded that the indicators in each variable has a good reliability or able to measure the construct.

\section{The Multicollinearity Test (Outer Model)}

Based on the output of SmartPLS, all independent variables of the study have a VIF value of less than 10. Then there is not relationship among the independent variables in this study, then the multicollinearity assumption is fulfilled.

\section{The Coefficient of Determination Test (R2) (Inner Model)}

Based on the output of SmartPLS, R2 value of the taxpayers compliance variable is at 0.664 or $66.4 \%$. This means that all independent variables, namely perception of tax officers service quality, tax understanding, perception of tax sanction, and public trust have a contribution of $66.4 \%$ to the of tax compliance as dependent variable, while the remaining $33.6 \%$ is contributed by other variables which not discussed in this study.

\section{The Stone Geisser Test (Q2) (Inner Model)}

Based on the output of SmartPLS, the Q2 value of all of the variables in this study is greater than 0 , which means that the model has a good predictive relevance value. 


\section{The Significance Test of Structural Path Coefficient (Inner Model)}

The path coefficient in the affect of the perception of tax officers service quality to the tax compliance is 0.207 with the t-statistic value is $2.369>1.99$. This means that the perception of the tax officers service quality has a positive and significant effect on tax compliance. The better perception of tax officers service quality, the higher of tax compliance of taxpayers. The results of this study supported hypothesis one (H1) that the perception of tax officers service quality has a positive effect on the taxpayers compliance.

The path coefficient in the affect of tax understanding to tax compliance is 0.239 with the tstatistic value as $2.914>1.99$. It means, the tax understanding of taxpayers has a positive and significant effect on the taxpayers compliance. The better tax understanding, the higher taxpayers compliance. The results of this study supported hypothesis two $(\mathrm{H} 2)$ that the tax understanding has a positive effect on the taxpayers compliance.

The path coefficient obtained from the affect of perception of tax sanction on the taxpayers compliance is 0.255 with the $t$-statistic value as $2.605>$ 199. It means the perception of tax sanction has a positive and significant effect on the taxpayers compliance. The better perception of tax sanction, the better taxpayers compliance. The results of this study supported hypothesis three (H3) that the perception of tax sanction has a positive effect on the tax compliance.

The path coefficient obtained from the affect of public trust to taxpayers compliance is 0.283 with the t-statistic value as 3.267> 1.99. It means the public trust has a positive and significant effect on the taxpayers compliance. The higher public trust, the higher taxpayers compliance. The results of this study supported hypothesis four $(\mathrm{H} 4)$ that the public trust has a positive effect on taxpayers compliance.

Table 2: The Description of Perception of Tax Officers Service Quality

\begin{tabular}{|c|l|c|}
\hline No & \multicolumn{1}{|c|}{ Dimension } & Average \\
\hline 1 & Reliability & 4,08 \\
\hline 2 & Assurance & 3,90 \\
\hline 3 & Tangibles & 4,13 \\
\hline 4 & Empathy & 4,12 \\
\hline 5 & Responsiveness & 4,18 \\
\hline \multicolumn{2}{|c|}{ Average } & $\mathbf{4 , 0 8}$ \\
\hline
\end{tabular}

Table 3: The Description of Tax Understanding

\begin{tabular}{|c|l|c|}
\hline No & \multicolumn{1}{|c|}{ Dimension } & Average \\
\hline 1 & Counting & 4,14 \\
\hline 2 & Paying & 4,13 \\
\hline 3 & Reporting & 4,12 \\
\hline \multicolumn{2}{|c|}{ Average } & $\mathbf{4 , 1 3}$ \\
\hline
\end{tabular}

Tabel 4: The Description of Perception of Tax Sanction

\begin{tabular}{|c|l|c|}
\hline No & \multicolumn{1}{|c|}{ Dimension } & Average \\
\hline 1 & The Severity of tax sanction & 4,06 \\
\hline 2 & The benefit of tax sanction & 3,91 \\
\hline 3 & The firmness of tax sanction & 3,92 \\
\hline \multicolumn{2}{|c|}{ Average } & $\mathbf{3 , 9 5}$ \\
\hline
\end{tabular}

Tabel 5: The Description of Public Trust

\begin{tabular}{|c|l|c|}
\hline No & \multicolumn{1}{|c|}{ Dimension } & Average \\
\hline 1 & Spirit of transparency & 3,93 \\
\hline 2 & Culture of Accountability & 3,93 \\
\hline 3 & People of integrity & 4,16 \\
\hline \multicolumn{2}{|c|}{ Average } & $\mathbf{3 , 9 8}$ \\
\hline
\end{tabular}

Tabel 6: The Description of Taxpayers Compliance

\begin{tabular}{|c|l|c|}
\hline No & Dimension & Average \\
\hline 1 & Administrative & 4,30 \\
\hline 2 & Material & 4,29 \\
\hline \multicolumn{2}{|c|}{ Average } & $\mathbf{4 , 2 9}$ \\
\hline
\end{tabular}

Tabel 7: R-Square

\begin{tabular}{|c|c|}
\hline Variable & R-Square \\
\hline The Taxpayers Compliance (Y) & 0.664 \\
\hline
\end{tabular}

Tabel 8: Q-Square

\begin{tabular}{|l|c|}
\hline \multicolumn{1}{|c|}{ Variabel } & Q Square \\
\hline $\begin{array}{l}\text { The Perception of Tax Officers } \\
\text { Service Quality (X1) }\end{array}$ & 0.399 \\
\hline The Tax Understanding (X2) & 0.432 \\
\hline $\begin{array}{l}\text { The Perception of Tax Sanction } \\
\text { (X3) }\end{array}$ & 0.374 \\
\hline The Public Trust (X4) & 0.362 \\
\hline The Tax Compliance (Y) & 0.368 \\
\hline
\end{tabular}

Tabel 9: Path Coefficient Score and t-Statistics

\begin{tabular}{|l|c|c|c|}
\hline $\begin{array}{l}\text { Relation } \\
\text { Between } \\
\text { Variable }\end{array}$ & $\begin{array}{c}\text { Path } \\
\text { Coefficie } \\
\text { nt }\end{array}$ & t-statistics & p-value \\
\hline $\begin{array}{l}\text { PKPPT -> } \\
\text { TKWP }\end{array}$ & 0.207 & 2.369 & 0.018 \\
\hline $\begin{array}{l}\text { TPWP -> } \\
\text { TKWP }\end{array}$ & 0.239 & 2.914 & 0.004 \\
\hline PSP -> TKWP & 0.255 & 2.605 & 0.009 \\
\hline $\begin{array}{l}\text { TKP -> } \\
\text { TKWP }\end{array}$ & 0.283 & 3.267 & 0.001 \\
\hline
\end{tabular}

Tabel 10: Contribution of Dimension of Perception of Tax Officers Service Quality

\begin{tabular}{|l|c|}
\hline \multicolumn{1}{|c|}{ Dimension } & Loading Score \\
\hline Reliability & 0,804 \\
\hline Assurance & 0,75 \\
\hline Tangibles & 0,947 \\
\hline Empathy & 0,688 \\
\hline Responsiveness & 0,691 \\
\hline
\end{tabular}


Tabel 11: Contribution of Dimension of Tax Understanding

\begin{tabular}{|l|c|}
\hline \multicolumn{1}{|c|}{ Dimension } & Loading Score \\
\hline Calculating & 0,935 \\
\hline Paying & 0,85 \\
\hline Reporting & 0,829 \\
\hline
\end{tabular}

Tabel 12: Contribution of Perception of Tax Sanction

\begin{tabular}{|l|c|}
\hline \multicolumn{1}{|c|}{ Dimension } & Loading Score \\
\hline The Severity of tax sanction & 0,735 \\
\hline The benefit of tax sanction & 0,879 \\
\hline The firmness of tax sanction & 0,921 \\
\hline
\end{tabular}

Tabel 13: Contribution of Dimension of The Public Trust

\begin{tabular}{|l|c|}
\hline \multicolumn{1}{|c|}{ Dimension } & Loading Score \\
\hline Spirit of transparency & 0,872 \\
\hline Culture of accountability & 0,839 \\
\hline People of integrity & 0,783 \\
\hline
\end{tabular}

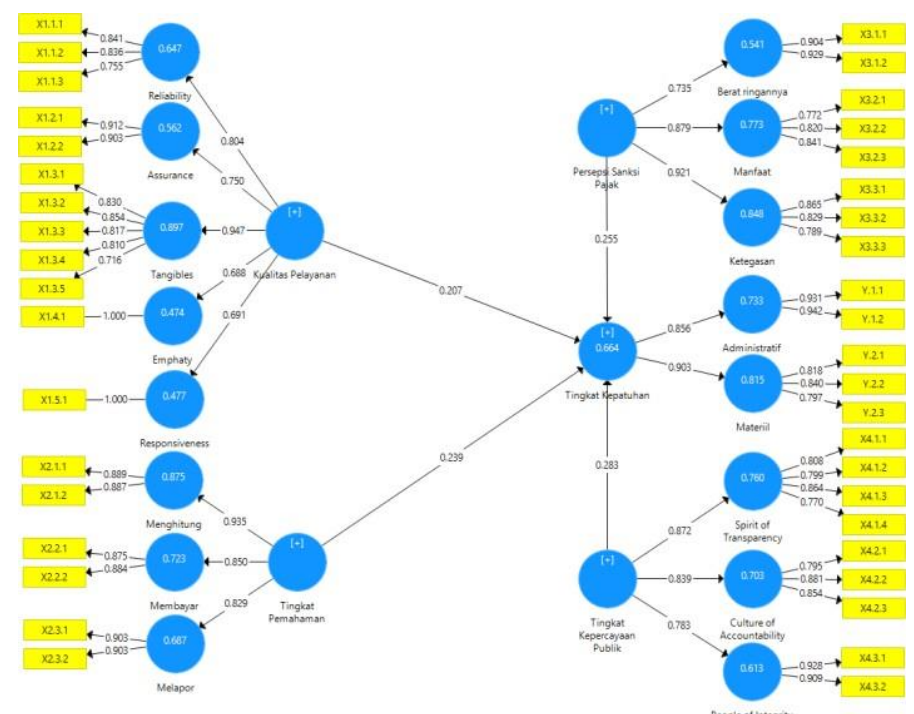

Display 1: Loading Factor/Path Coefficient

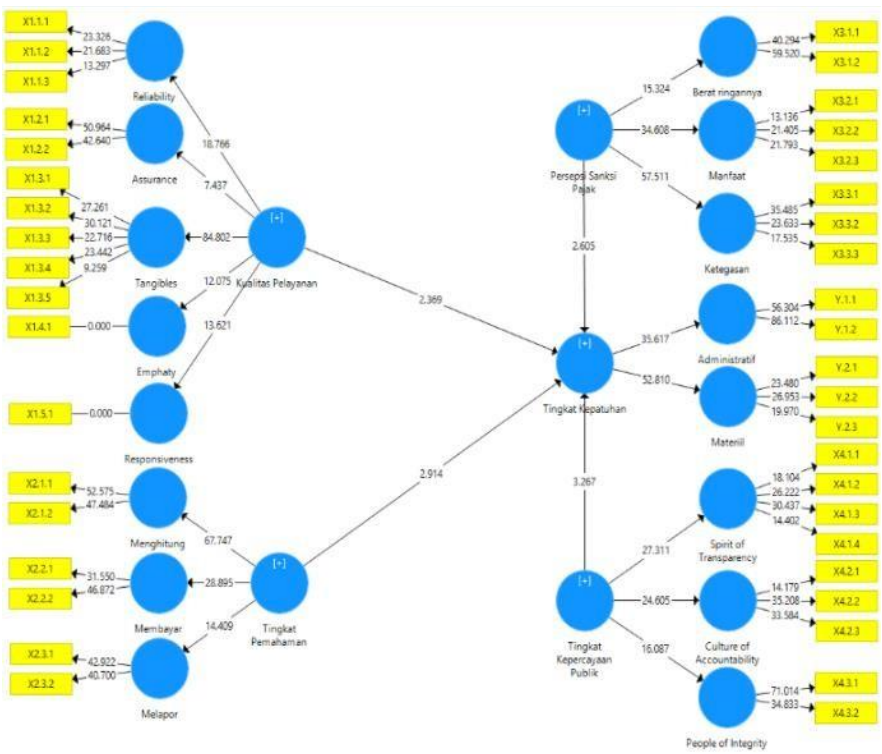

Display 2: Inner Model/t-statistics

\section{DISCUSSION}

According to the Attribution Theory, the behavior of taxpayers to comply with is caused by the internal factors and the external factors of the taxpayer.
In this study, the authors tested the influence of perceptions of tax officers service quality, tax understanding, perception of tax sanction, and public trust to taxpayers compliance, which service quality and 
tax sanction are the external factors of the taxpayers , and understanding and trust are the internal factor of the taxpayer which also influences the taxpayer's compliance behavior.

In this study it is also known how much the contribution of each dimension is in forming the variable of perception of tax officers service quality, tax understanding, the perception of tax sanction, and public trust, so it can be seen which dimensions have the greatest contribution to it's variable, which then influences taxpayers compliance.

The quality of service can affect the taxpayers compliance. The great service quality will provide comforty and convenience for the taxpayers to carry out their tax obligations and will encourage taxpayers to comply with. The service quality is measured from 5 aspects, namely: reliability, assurance, tangibles, empathy, and responsiveness, which is tangibles has the largest contribution at 0.947 (table 10), which means that the physical facilities of Tax Service Office (KPP) is the most important aspect in realizing the good service quality.

Based on the statistical tests and the significance test, it is known that the perception of tax officers service quality has a positive and significant effect on the taxpayers compliance. The better service quality, the better taxpayers compliance. This result is consistent with the research conducted by Akinboade (2015) and Alabede, Ariffini, and Idris (2010) which concluded that service quality has a positive and significant effect on tax compliance.

The tax understanding can affect taxpayers compliance. The taxpayers who understand taxation will be eased in carrying out their tax obligations and encourage them to comply with. The tax understanding is measured by 3 aspects, namely the understanding of calculating, paying, and reporting taxes, where the understanding of counting has the largest contribution at 0.935 (table 11). Then counting is the most important aspect that must be understood by the taxpayers.

Based on the statistical tests and the significance test, it is known that the tax understanding has a positive and significant effect on the taxpayers compliance. The better tax understanding, the better tax compliance. This result is consistent with the research conducted by Mahfud, Arfan, Abdullah (2017) and Nurhakim, Pratomo (2015) which concluded the tax understanding has a positive effect on the taxpayers compliance.

The perception of tax sanction can affect the taxpayers compliance. If the tax sanction is applied effectively, it will certainly make taxpayers to be afraid to commit violations and will become compliant. The perception of tax sanction is measured by three aspects, namely: the severity of tax sanction, the benefits of tax sanction, and the firmness of tax sanction, which the firmness of taxation has the largest contribution at 0.921 (table 12). It means that the firmness is the most important aspect in applying tax sanction.

Based on the statistical tests and the significance test, it is known that the perception of tax sanction has a positive and significant effect on the taxpayer compliance. The better perception of tax sanction, the better taxpayers compliance. This is in line with the research by Susmita, Supadmi (2016) and Lubis (2017) which concluded that the tax sanction has a positive effect on taxpayer compliance.

The public trust can affect the taxpayers compliance. The taxpayers who believe that the tax they paid will be used for the benefit of all of the people, will encourage taxpayers to obey. The public trust is measured by three aspects, namely: spirit of transparency, culture of accountability, and people of integrity, which spirit of transparency has the largest contribution at 0.872 (table 13). It means that the transparency of Directorate General of Tax (DGT) institutions is the most important aspect in realizing public trust.

Based on the statistical test and the significance test, it is known that the the public trust has a positive and significant impact on the tax compliance. The better public trust, the better taxpayers compliance. This is in line with the research by Birskyte (2014) and Amriani, Herawati, Darmayanti (2014) which concluded that if the trust increases, then compliance will also increase.

\section{CONCLUSION}

Based on the results of the discussion presented before, it can be concluded that:

- The perception of tax officers service quality has a positive and significant effect on the tax compliance. The better service quality, the better compliance of taxpayers. The good quality service will give comforty and convenience to the taxpayers so that it will encourage taxpayers to comply with.

- The tax understanding has a positive and significant effect on the taxpayers compliance . The better tax understanding, the better taxpayers compliance. This is because of the taxpayers who understand about tax, will be easy to carry out their tax obligations then will motivate them to do their tax obligation.

- The perception of tax sanction has a positive and significant effect on the tax compliance. The more effective of tax sanction application, the better tax compliance. This is because of the application of effective tax sanction creates fear to the taxpayers to commit violations and then taxpayers will become compliant. 
- The public trust has a positive and significant effect on the tax compliance. The better public trust in their government, the better tax compliance. Taxpayers will voluntarily pay their taxes if they believe in government will use the taxes for the welfare of the peoples.

\section{SUGGESTION}

Based on the results of the discussion and conclusions before, the authors provide the following suggestions:

- For further research, the authors suggest to add the moderating variables to find out variables that can moderate the influence between service quality, tax understanding, tax sanction, and public trust as an independent variable on the taxpayers compliance as the dependent variable.

- For tax regulators, in order to improve the taxpayers compliance, it is expected to pay attention to the tax officers service quality, the tax understanding of taxpayers, the application of tax sanction, and the public trust. Then prioritizing on the weakness side, namely: the competence and the friendliness of tax officers, the effectiveness tax sanction application, and the transparency and the accountability of DGT institutions. The good training for the government employee and the good Standard Operating Procedure (SOP) can be done to improve those aspects.

\section{REFERENCE}

1. Mulyani, S. (2016).Sri Mulyani: Regulasi yang Rumit Bikin Penerimaan Pajak RI Rendah. Diakses pada 5 Januari 2018 dari World Wide Web: https://finance.detik.com/berita-ekonomi-bisnis/d3325580/sri-mulyani-regulasi-yang-rumit-bikinpenerimaan-pajak-ri-rendah

2. James, A. (2016).Menkeu: Kepatuhan Wajib Pajak Masih Rendah. Diakses pada 5 Januari 2018 dari World Wide Web: https://koransulindo.com/menkeu-kepatuhan-wajibpajak-masih-rendah/

3. Saksama, H. Y. (2016). Dua Bukti Rendahnya Kepatuhan Pajak di Masyarakat. Diakses pada 5 Januari 2018 dari World Wide Web: https://www.viva.co.id/berita/bisnis/847916-duabukti-rendahnya-kepatuhan-pajak-di-masyarakat

4. Alabede, J. O., Ariffin, Z. Z., \& Idris, M. D. (2010). Tax Compliance and The Moderating Role of Taxpayer's Financial Condition: A Proposed Model for Nigeria. IPBJ, 2(1), 25-47.

5. Madjid, S. (2015). The Effect Tax Audit Quality and Service Quality On Tax Reporting Compliance. Research Journal of Finance and Accounting Vol.6, No.12, 2015.

6. Xin, M. H., Khai, K. G., Fong, S. L., \& Chen, N. H. (2015). Factors Affecting Individual Taxpayers' Compliance in Malaysian Tax Filing System. The International Journal of Business \&
Management, 3(9), 339-347.

7. Engida, T. G., \& Baisa, G. A. (2014) Factors Influencing Taxpayers' compliance with The Tax System: An Empirical Study of Mekelle City, Ethiopia. e-Journal of Tax Research, 12(2), 433452.

8. Lesnik, T., Kracun, D., \& Jagric, T. (2014). Tax Compliance and Corporate Income Tax-The Case of Slovenia. Lex Localis, 12(4), 793-811.

9. Birskyte, L. (2014). The Impact of Trust in Government on Tax Paying Behavior of Nonfarm Sole Proprietors (Romania). The Journal of "Alex and ruIoan Cuza" University from Iasi, 61(1), 1-15.

10. Dharma, M. T. dan Ariyanto, S. (2014). Analisis Faktor-Faktor Yang Memengaruhi Tingkat Kepatuhan Wajib Pajak Orang Pribadi di Lingkungan Kantor Pelayanan Pajak Pratama, Tigaraksa Tangerang. Binus Business Review, 5 (2), 497-509.

11. Suartana, I. W., (2010). Akuntansi Keprilakuan Teori dan Implementasi. Denpasar: Andi Offset.

12. Tjiptono, F., \& Chandra G. (2012). Pemasaran Strategik. Yogyakarta: Andi.

13. Waluyo \& Ilyas, W. B., (2003). Perpajakan Indonesia. Jakarta: Salemba Empat.

14. Pusat Bahasa Depdiknas. 2016. Kamus Besar Bahasa Indonesia. Jakarta: Balai Pustaka.

15. Mardiasmo. (2018). Perpajakan Edisi Revisi 2018. Yogyakarta: Andi.

16. Devano, S., \& Rahayu, S. K. (2006). Belajar dan Faktor yang mempengaruhinya. Jakarta: Rineka Cipta.

17. Zain, M. (2008). Manajemen Perpajakan. Jakarta: Salemba Empat.

18. Turnipseed, M. (2009). Public Trust Doctrine Could Aid Management of U.S. Oceans. Diakses pada 10 Januari 2018 dari World Wide Web: https://nicholas.duke.edu/about/news/public-trustdoctrine-could-aid-management-us-oceans

19. Frederickson, H. G., \& Ghere G. K. (2015). Ethics in Public Management. London dan New York: Routledge.

20. Siat, C. C., \& Toly, A. A. (2013). Faktor-Faktor yang Mempengaruhi Kepatuhan Wajib Pajak Dalam Memenuhi Kewajiban Membayar Pajak di Surabaya. Tax \& Accounting Review, 1(1).

21. James, S., \& Alley, C. (2010). Tax Compliance, Self Assessment, and Tax Administration. New Zealand: Department of Accounting, University of Waikato.

22. Rahayu, S. K. (2009). Perpajakan Indonesia Konsep \& Aspek Formal. Yogyakarta: Graha Ilmu. 